Portland State University

PDXScholar

1975

\title{
Verbal models provided for mentally retarded children by parents
}

Lance Tsugawa

Portland State University

Follow this and additional works at: https://pdxscholar.library.pdx.edu/open_access_etds

Part of the Speech Pathology and Audiology Commons Let us know how access to this document benefits you.

Recommended Citation

Tsugawa, Lance, "Verbal models provided for mentally retarded children by parents" (1975). Dissertations and Theses. Paper 2526.

https://doi.org/10.15760/etd.2520

This Thesis is brought to you for free and open access. It has been accepted for inclusion in Dissertations and Theses by an authorized administrator of PDXScholar. Please contact us if we can make this document more accessible: pdxscholar@pdx.edu. 
Ax ABSTRACT OF THS THRSIS OF Lance Tsugawa for the Master of Science

In Speech Communications Bhphas is in Speech Pathology/Audiology presented November 13. 1975.

Titles Verbal Models Provided for Mentally Retarded Children by Parents.

APFROVED BY MEMBERS OF THE THESIS COMITTHE:

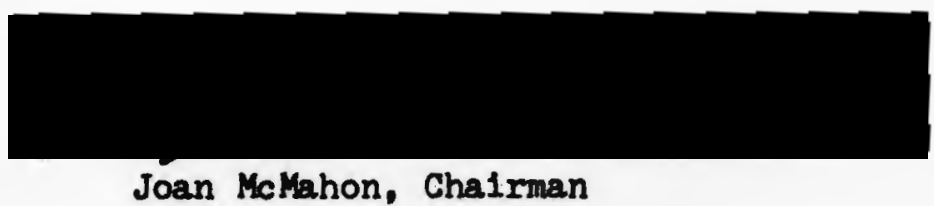

Joan McMahon, Chalrman

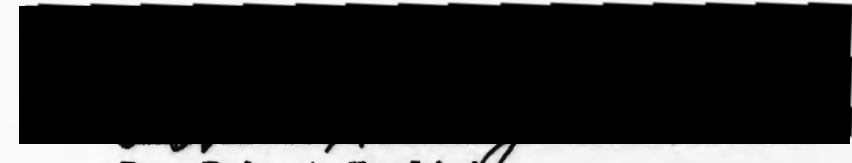

De. Robert Englisb

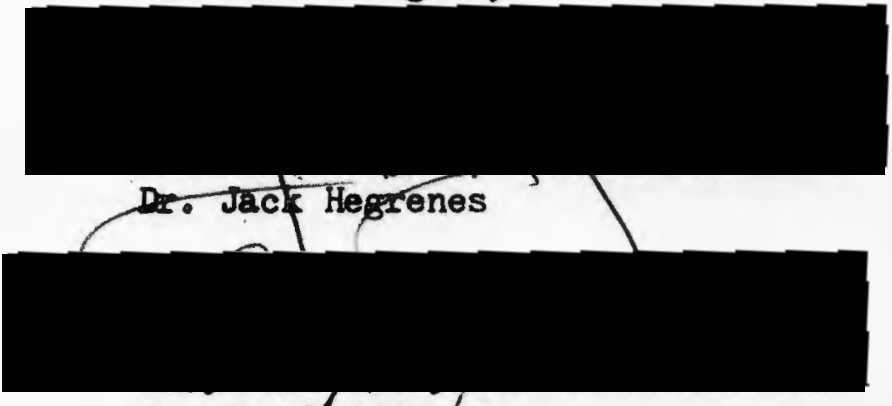

Dr. Dary Anderson

Recent Investigation has focused on the nature of adult-child verbal interactions. The research has exanined the language of nothers and other adults when assembled with both normal and retarded children. The present study was undertaken to test the hypothes is that mothers of children with Down's Syndrome and mothers of normal children would present different language characteristics to a Down's Syndrome child versus a normal child. Type-token rat1o, a measure of the subject's language diversification, was used as the behavioral measure. 
The findings indicated that all mothers presented smaller typetoken ratios to the Down's Symdrome child than thase addressed to the normal child. The results were statistically significant at the .0005 level of confidence on a one-talled test. No significant differences in type-token ratio were found between groups of mothers of Down's Syndrome children and mothers of normal chlldren in speeches addressed to the Down's Syndrome chlld or to the normal child. Both groups of mothers modifled their language similarly to each child. 


\title{
VIRBAL MODELS PROVIDED FOR \\ MANTALIY RETARDED CHILDREN \\ BY PARENTS
}

\author{
by \\ Iance Tsugara
}
A Thesis Subaltted in Partial Pulfillment of the Requirements for the Degree of

\section{MASTER OF SCIENCE IN SPEECH COMUUNICATION}

$$
\text { with an enphasis in }
$$

SPEECH PATHOLOGY AND AUDIOLOGY

Portland State University 
TO THE OFFICE OF GRADUATE STUDIES AND RESEARCH,

The members of the Comittee approve the thesis of Lance

Tsugawa presented November 13, 1975.

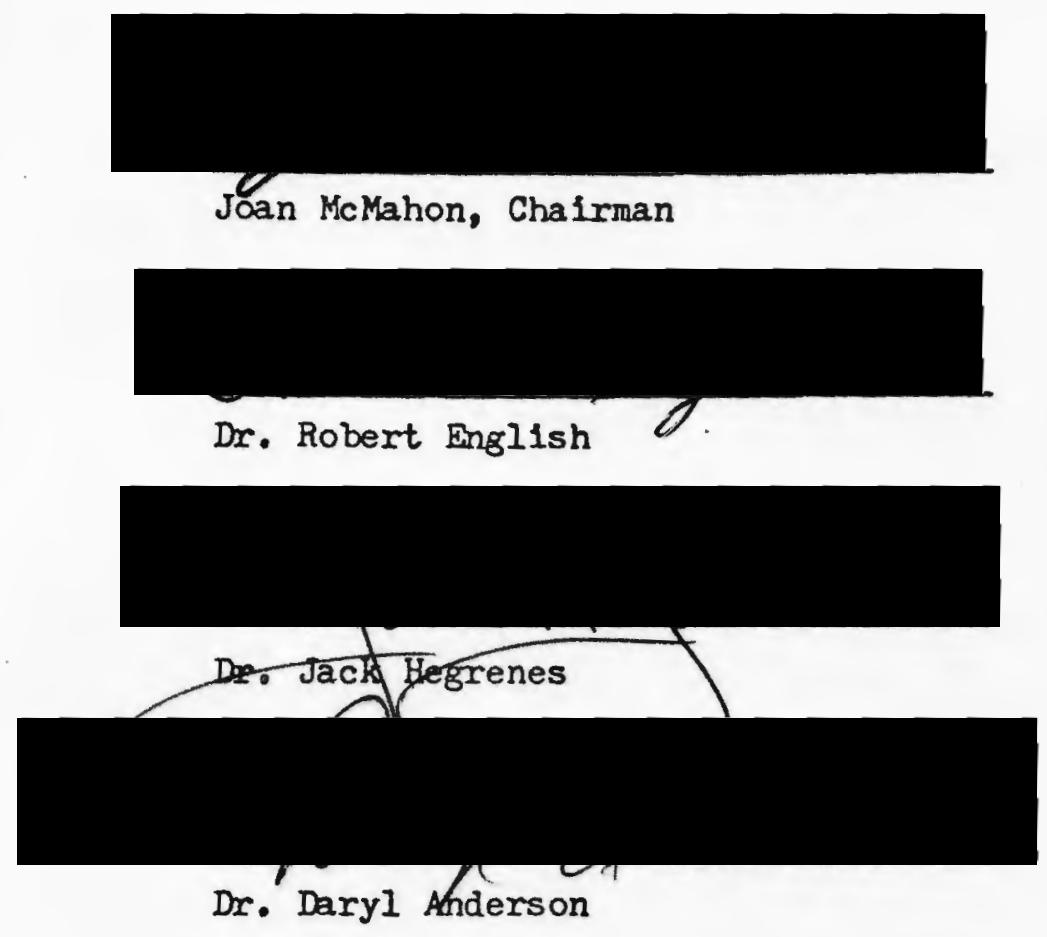

APPROVED,

Robert W. Vogelsang Head, Depgrtment of Speech Communication

Richard B. Halley, Dean of Graghrate Studies and Research November 13, 1975 


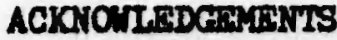

W1th grat1tude and apprecintion, I would like to thank my chaiman and graduate advisor, Joan Fellhon, for her support and advice through the period of this research. It was a long and senaingly diffleult task made eesior by hor ane and practical guldance. Spacial thanics to my conmittee for thatr time, knowledge, and consideration, Dr. Robert English, Dr. Daryl Anderson, and Dr. Jack Hegrenes,

To ny wife, Arlynn, ay love and deepest apprectation for the wealth of patience and consideration she extended to me during my graduate study. Thank you, honey. We made 1t! 
TABLE OF CONTRNTS

PAGE

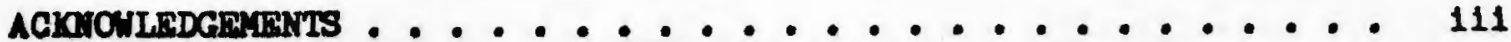
LIST OF TABLES . . . . . . . . . . . . . . . . . . v

\section{CKAPIFR}

I INTRODUCTION AND STATIRIRNT OF PURPOSE . . . . . . . 1

II RRIIR OP THR IITERATURR . . . . . . . . . . 4

III METHODS AND PROCEDURTS .............. 14

Subjects .................. 14

Instrumantation ................. 14

Bxperinental Condition ............ 15

Analysis of Data ............... 16

IV RRSULIS AND DISCUSSION ............. 17

Results .................. 17

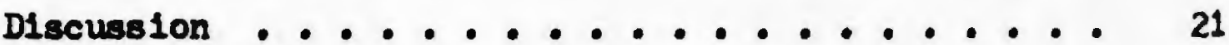

V SUMARY AND IMPLICATIONS .............. 27

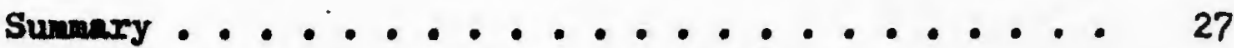

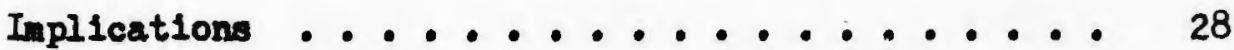

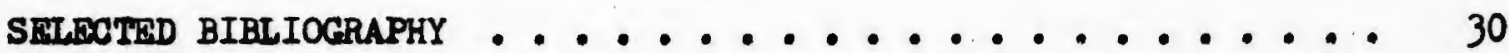

APPANDIX - Toys Used is St1rulus Itons In Mothor-Ch1ld Dyads . . . 32 
CHAPTER I

INTRODUCTION AND STATEMIENT OF PURPOSE

INTRODUCTION

Fundarental to the process of language development in children is the amount and quality of environmental stimulation they receive. Wilkinson (1971) has stated that the nature of the adult-child dialogue 1s of primary inportance in the language development of children. The way children are talked to by aduits, their parents, and in particular their mothors, determines in large measure their Iinguistic growth. Wilkinson (1971, p. 104) further explains :

The mother's language is the model, and that the good mother is consclously or unconsclously aware of this is indicated by the way she often speaks simple, distinct, well-formed sentences to her child. With the child's own language she does several things, notably, seizing upon sounds in his stream of babble and reinforcing them and a little later, expanding his own telegraphic contractions in a varlety of transforaations. The early teaching lo particularly concerned with supplying nouns and verbe by giving names to things and actions.

Euphasis placed upon parent-child language activities in the home appears to be a significant factor in Iinguistic development. Mothers vary greatly in how they stimulate their children's language growth. Sone use baby talk, some are vory silent, while others are more consistently verbal. The linguistic environment of the languagelearning child does not remain constant, but varies arkedly within the nother-child dyad, and in response to a number of variables. 
The question of what is appropriate stimulation is further complicated if the child is mentally retarded. Language delay is common, and in many cases severe. The role of the nother in stimulating language development in her mentally retarded child is yet unclear. How she talks to her child may significantly influence the degree to which he will achleve linguistic competence.

\section{STATHENT OF PURPOSE}

The purpose of this study was to analyze the language mothers of children with Down's Syndrome and mothers of normal children addressed to a Down's Syndrome child with delayed speech and language in comparison to the language they addressed to a child of similar chronological age with normal speech and language. Typo-token ratio (TTR), which is the ratio between the number of different words (types) to the total number of words (tokens) in a given sample of speech (Spradlin and Rosenberg, 1964). was analyzed within the speech addressed to both the Down's Syndrome child and the nornal child by both groups of mothers (see procedures section).

The following null hypotheses were testeds

1. Averaged type-token ratios within speech addressed to the Down's Syndrome child will be equal to those addressed to the normal child by all mothers when considered as a group.

2. Kothers of children with Dow's Syndrome will have averaged type-token ratios equal to those of mothers of normal children in the speech addressed by both groups of mothers to the Down's Syndrome child. 
3. Nothers of children with Down's Syndrome will have averaged type-token ratios equal to those of nothers of normal children in the speech addressed by both groups of nothers to the normal child. 
CHAPTER II

\section{REVIEN OF THE LITERATURE}

Interest in how mature adult speakers talk to chlldren has increased in recent years. Brown and Bellug1 (1964) studied the Iinguistic interaction between a mother and her normal two-year old child and found the mother's speech differed from the speech adults use to each other in many ways. Her sentences were short and simple; for the most part, they were largely the kinds of sentences the child nould produce a year later.

Snow (1972), in an unpublished doctoral dissertation, found that the speech of middle-class mothers was simpler and more redundant when they spoke to two-year olds than when they spoke to ten-year olds. Similar findings were made by Phillips (1971) in an 1nvestigation of the speech mothers used with their children and that which they used with other adults. The speech to adults had consistently longer utterances, more verbs per utterance, more modiflers per utterance, a greater proportion of function words, a smaller proportion of content words, and more verb forms than the mothers' speech to their children. Broen (1972), In studying the verbel environment of the languagelearning child, found mothers used fewer words per minute, had fewer disfluencles, and a smaller type-token ratio in speech directed toward their children then in speech addressed to their older children. Larger TTRs indicate a greater number of different words used. Broen (1972, p. 15) further reported that speech used with the young children 
contalned sentences that were well marked by pauses. She stated.

False or confusing information in the form of extraneous confunctions and broken sentences is absent. Single rords are used as sentences more often in speech to young children then they are in speech to older chlldren or adults.

Brown and Bellugi (1964) investigated the role of imitation in mother-child dialogues. Analys is of the children's speech indicated many of their utterances were reduced imitations of the mother's utterances. Words were omitted, but the word order of the sentences was maintained. Conversely, mothers often imitated their children with expanded utterances. Incomplete chlld utterances were often expanded by the mothers to the nearest properly formed complete sentence. They concluded that mother-child interaction is, much of the time, a cycle of such reductions and expansions.

Cazden (1969) investigated the effect of treating languagedelayed children with three experimental conditions. One group recelved intensive and deliberate expansion of their utterances, a corrective process. The aecond group recelved models of an equal number of well-formed sentences that were deliberately not expensions. A third group, acting as a control, received no stimulation. The findings indlcated modeling, not expanding, was the more effectlve stinulation technique.

The importance of mature speech models for the child to perceive and imitate has been pointed out by a number of researchers (Brown and Bellug1, 1964; Cazden, 1972, W1lkinson, 1971). The degree to which these models are a factor in the process of Increasing the child's linguistic growth seems to be related to the mother's interest in language training during the preschool years. This may be demonstrated 
In her actual attempts to foster the developient of linguistic skill. Molymoaux (1972) exanined adult speech through interviews with parents of children with normal speech and language and parents of chlldren who ware diagnosed as speech and language delayed. The findings indicated a signiflcantly greater percentage of mothers of the normal group read to thoir chlldren regularly and had commoned thie practice when their children were several years younger. They encouraged menorizing nursery rhymes and regularly had informal chats with their children to discuss their activities. The results strongly suggested that children of the norral group were consistently exposed to greater anount of parental speech stimulation than children of the delayed group.

A large research project, dealing with language as a factor in the soctalization of children, was conducted in London by Brandeis and Henderson (1972). Information was obtained on maternal att1tudes toward language through interviews with the mother. The children's language abllity was measured at age five and again at age seven. They concluded that a chlld's measured language ability was related to the ways mothers responded to their chlldren's questlons and gave explanations.

Investigation of adult verbal behavior with retarded children is relatively linited and of recent origin. A serles of the most recent studies in this area were performed at the Parsons State hospltal and Training Center, Parsons, Kansas, In the flrst of these, Spradin and Rosenberg (1963) based their research on the hypothesis that adults may respond to low lovel verbalizers in such a way as to perpetuate a 
low level of performance. In their study, adult subjects were asked to Interviow "Iow" and "high" verbal, mentally retarded children. Thelr primary concern was the ways in which the verbal levels of these chtldren would selectively influence the language used by adults. They suggested that children of low verbal lovels would influence the adult subjects to ask a reater proportion of blnary questions, those calling for a two-cholce answer such as "yes" or "no." A greater percentuge of questions addressed to children of higher verbel levels would be nultiple or "opon-ended."

It appeared I1kely that low verbal children would be nore prone to respond to binary rather than multiple questions, and consequently, the children would "condition" the adults to use a greater proportion of binary questions. They assuned that fallure of the child to respond to a epeciflc type of adult question would cause the adult to ext1nBuish in that behavior. The results of the study indicated low level children elicited a larger proportion of binary questions than did the high verbel children. Of Interest also is the finding that adults used a significantly larger average type-token rat10 with the high verbel chlldren.

Additional studies wore performed using this same interpersonal model with some extensions and modifications. Slegel (1963a) constructed "play therapy-11ke" oltuations to test the hypothes is that adult verbel behavior would vary according to the verbal level of the mentally retarded children with whom they interacted. The subjects of the atudy were two adults, a 44-year old housenife and a 22-year old college student. They were assembled with four "low" verbal and four 
"high" verbal level montally retarded children. Moesures of adult words, adult questlons, and Mean Length Response (ILR) revealed no signiflcant differences in the adult verbel behavior with high or low level children.

In a third study, Slogel and Harkins (1963) assembled 21 college students with one high vorbal level and one low verbel level mentally retarded child in a structured (teaching) and an unstructurod (free) situation. Their analysis of data indicated the adults used nore responses, greater MRs, and larger TTRs with the high verbal children. The type of situation exerted considerable influence on both child and adult verbal behavior. The adults asked more questions in the unstructured situation and made more responses in the structured situation. They also used more words, presented longer MLRs, and larger TIRs in the structured situation. The children were found to use considerably fewer words during the structured condition.

A subsequent study by Slegel (1963b) assembled adults with high and low verbal level mentally retarded children. Half of the adults were assifned to an "Interview" condition, the other half to a clinical condition whore pontaneous child verbalization was encouraged. Of the noasures analyzed, adults in both experimental conditions were found to use signiflcantly larger TIRs, longer MLRs, and ask fewer questions of the high level children.

In a later study. Slegel (1963c) assembled 20 adults in a structured (teaching) and an unstructured (free) situstion with one retarded child who had been labeled "high" and another who had been labelod as "lou" in verbal behavior. The labels nere assigned randomly 
wthout regard for the actual verbal levels of the children. The question posed was whether adults respond to children labeled as "hIgh" or "low" the same as to thase chlldren who were actually high or low in verbel ability. The measures used were adult TTR, muber of adult questions, vocal responses and words. Analys is of the results indicated the adults did not respond differently on any of the measures on the basis of the label assigned.

Since the children were all of low verbal abilities, and no apprectable differences were found in adult language, the labels assigned seemed to exert no influence. Siegel (1963c) felt the obvious varlable responsible for the results might be the actual verbal level of the children. The procedures and criterla neasures in this study were comparable to those in the Slegel and Harkins (1963) study. Designations of high and lor verbal levels in the latter study, however, referred to actual differences in verbal skills rather than random labels. Slegel compared the mean scores of adult verbal behavior with low level children in both investigations. All measures were very sinflar. In partlcular, the aduits had averaged TTRs of .390 as compared to .385 in the Siegel and Harkins (1963) study. In the face of contradictory information, the verbal characteristics of the retarded children seoned to exert considerable influence over adult responses. Ilegel (1963, p. 32) further explainss

In interactions between retarded chlldren and teachers or cinicians for example, the adult is typically considered to be in some manner manipulating or modifying the behavior of the chlld. However, the child may in turn exert considerable influence over the persons in his environment. In the realn of language, the degree of verbal stimalation the child experiences may be related to the kinds of verbal or other cues he presents. Thus, the child whose speech 
behavior is severely linited or inappropriate may evoke patterns of responsea from adults that discourage him from extending or improving his verbal performance.

In research conducted at the Parsons State Hospital, Invest1gators in a number of studies (Slegel, 1963b; Slegel, 1963c; siegel and Harkins, 1963: Sprediln and Rosenberg, 1963) consistently found larger averaged TTRs in adult speech with high verbal level retarded children compared to low level retardates. The sinilarity of these findinge in several studies seems to indicate the effect is not an loolated one.

Snow (1972) Investigated the language of mothers in interaction with their 2 year old and 10 year old normal children and found that the younger children played some role in elfclting their mothers" speech modifications. The taok difficulty of the experimental situation had no effect on the production of the mothers' speech modifications, Indicating those modifications rere not a response to the children's cognitive immaturity. Rather, the kind of sinplification for the young children seemed to be a product of the adult's communicative competence and the cues provided by the child. Snow stated that the children were less attentive and less compliant when listening to unmodifled adult speech. She felt these responses to unmodifled speech might be the means by which children elicit speech modifications from adult speakers.

Hegrenes, Marshall, and Coldsteln (1973) using Skinner's (1957) classifications of verbal operants, investigated the verbal interactions of 3 to 5 year old, mentally retarded and normal children with their mothers. Recordad samples of speech were obtained during free-play 
situations and evaluated in torms of numbers of tacts, mands, intraverbals, and echoics for both mothers and children. Their results Indlcated a greator frequency of tects, ands, and intraverbals among chlldren of the non-rotaried group, and a greater frequency of echolcs emitted by the retarded children. Mothers of both groups were qualitatively similer in their usege patterns. Mands occurred most frequently, with tacts, Intraverbals, and echoics following in order of frequency. Of Interest is the fact that no significant differences were found between nothers of retarded and non-retarded children in their frequency of tacts, intraverbals, and echoics emitted. Manding, however, occurred with greater frequency anong the mothers of retarded children.

The researchers felt this may be explained by a number of factors. The child, with his decreased mental capacity and relatively increased physical mobility. might require greater external control by the parent through manding. The lower expressive ability of the retarded child also may serve to extinguish the nother's tacts, Intraverbals, and echolcs, leaving the mother with only an habitual manding response. Assuming the child responds to the nother's commands with a motoric response rather than a verbul one, her manding behavior may be further relnforced. The child, with his lower expressive abllity, may respond to commands by acting rather than talking. This may also be responsible for the asymnetry in frequency of verbal responses betxeen the mothers and children. The actual verbel levels of the retarded children in this study seen to be an important factor in influencing their mother's language. 
In general, the speech of mentally retarded children is often significantly delayed. Children with Dorn'B Syndrose, in particular. ". reveal a deceloration of physical and mental development with the result thet they grow and mature at a slower rate (Benda, 1960)." Down's Symdrome, comonly referred to as Mongolism, is a genetic disorder and one of the rost common causes of nental retardation. Jordan (1960) has found a close relationship between Down's Syndrome and the probabli1ty of language disorders. In extensive research, Ionneberg. N1chols, and Rosenberg (1962) have studied language development of the Down's Syndrone child. They followed 61 Down's Syndrome children Ilving at home over a three-year period using a variety of poychological and language assessments. Of particular interest is the analysis of the ability of children displaying Down's Syndrome to acquire rules of syntax and morphology. The results suggest their intellectual initations do not produce bigarre behavior forms, but merely result in an arrest of development at a primary level.

The types of verbal cues the child with Down's Syndrone presents to the mother may be sinilar to that of a younger, normal child, but the degree to which his mother will modify her speech to provide eppropriate stimulation is unknow. The ways in which she fosters the language development of her child may be an influential factor in his growing Iinguistlc competence. Over time, the Down's Syndrone child will develop speech and language at a signiflcantly slower rate than his normal counterpart (Ienneberg, 1962). The mother nay produce speech which is short and simple, it may be roadily understanitable to the child, but be inadequate as a stimulating language model. Con- 


\section{CHAPTAR III}

\section{METHODS AND PROCEDURES}

\section{METHODS}

\section{Subjects}

The subjects utilized in the present investigetion consisted of twelve mothers. Six were nothers of children with Down's Syndrone, selected randomly from the flles of the Crippled Children's Division (CCD). University of Oregon Haalth Sclonces Center, and $81 x$ mero mothers of nornal chlldren who were selected at random from the general population of the greater Fortland metropolitan area.

One boy of 8-2 years of age with Down's Syndrome and delayed speoch and language was selected from the files of CCD to serve as the experimental subject. A second boy, 7-8 years of age with normal speech and language served as the control subject. Nelther child was the offepring of any of the twelve prevlously selected mothers.

\section{Instrumentation}

The Utah Test of Language Developaent (Kochan, Jex and Jones, 1967), a receptive and expressive language instrument, was used as the language measure to evaluate the level of each child's language. The child with Down's Syndrome achleved a language age of 2-11 years while the normal child recelved a language age score at the 8-3 year level.

Type-token rat1o (TTR) (SpradIIn and Rosenberg. 1964), a measure of the diversification of the subject's Ianguage, was used to 
versely, the mother's speech may be too complex for the child to comprehond. By describing the actual types of speech mothers present to their montaily retarded child, a basis for further research w1ll be established regarding the question of what is optlmal language stimulation for mentally retarded child. The present study investigates one parameter of the IInguistic model provided for retarded children by mothers. 
analyze the mothers" responses. After completion of all sessions, typed transcripts from the 10-minute recordings were prepared of the mothers' speech by the investigator. All remarks of the child and unintellifible words of the mothers were omitted. To calculate TIR, the middle 200 words were extracted from individual transcripts for each session. The number of different words (types) were counted and divided by the 200 word (tokens) sample to yield a ratio. Protocol for counting words was taken from Johnson, Darley and Sprlestersbach's (1963) method for computing MLR. For example, contractions, such as "It's" and "I'm" were counted as two words; compound nouns such as "Mickey Mouse" were counted as one word. In addition to this protocol, words that occurred in singular and plural forms, or present and part tense were counted as two different words. For example, "horse" and "horses", or "walk" and "walked" were counted as two different words in a particular sample.

Hean or averaged TTRs were computed for groups of mothers of normal children, mothers of Down's Syndrome children, and all mothers combined, in interactions with each child.

\section{PROCEDURES}

\section{Experimental Condition}

The order in which mothers were assembled with a particular child was randonized, with each nother spending 10 minutes with each ch1ld. Mothers were instructed to play with the child and encourage hin to play and "chat" Informally. They were informed that the purpose of the etudy was to observe some of the behaviors of a retarded 
child when interacting with a varlety of adults. Additionally, they were told their interactions with a normal child also would be observed for comparison with their interactions with the retarded ch11a.

The experimental sessions were conducted in an elght by twelve foot clinical room, equipped for audio and visual observation. A Panasonic cassette recorder, model \#RQ 309 AS, was placed in the room out of the participant's vision to record the ten minute sessions. All subjects were informed the sessions would be recorded.

To ald the nothers in stimulating free-play and conversation, each was given a number of simple toys which they were told to use at their discretion. Five different toys were selected randomly for each ten alnute session from a pool of fiftean toys. The toys, which would provide Interest across a varlety of age levels, were selectad through the suggestions of a staff occupational therapist at CCD (see Appendix).

Bach child was seen by one mother of a normel child and one mother of a child with Down" Syndrome for a total of two ten-minute seasions for each child periay. The $81 x$ days needed to complote the experiment were spaced over a two-week perlod to avoid child fatigue.

\section{Ansysis of Data}

Data from the transcripts were analyzed using t-tests to deteraine whether significant differences occurred between averaged TTRs presented by groups of mothers to the Down's Syndrame child and the normal child. 
CHAPIER IV

RESULTS AND DISCLSSION

RESULTS

The purpose of this investigetion was to determine if there was a signifleant difference between the language presented by mothers of Down's Symdrome children and nothers of normal children to a child with Down's Symdrome, who is delayed speech and language, and a child of sinilar age with normal speech and language. The null hypothoses to be tested in this investigation were:

1. Averaged type-token ratios within epeech addressed to the Dow's Syndrome child will be equal to those addressed to the normal child by all mothers when considered as a group.

2. Mothers of children w1th Down's Syndrome will have typetoken ratios equal to those of nothers of normal children in speech both groups of mothers address to the Down's Syndrone ch1ld.

3. Mothers of children with Down's Syndrome w1ll have typetoken ratios equal to those of mothers of normal children in speech both sroups of sothers address to the normal child.

A summary of TIR presented by nothers to each child is presented In Table I. TTRs in speeches presented by nothers of Down's Syndrone chtldren to the Down's Symdrome child ranged from .365 to .435 . and from .425 to .545 for the normal child. TTRs of nothers of normal children in speeches addressed to the Down's Syndrone child ranged 
TABLE I

AVWRAE GROUP AND INDIVIDUAL

TTR FOR HOTHEAS IN

MOTHER-CHILD INTERACTIONS

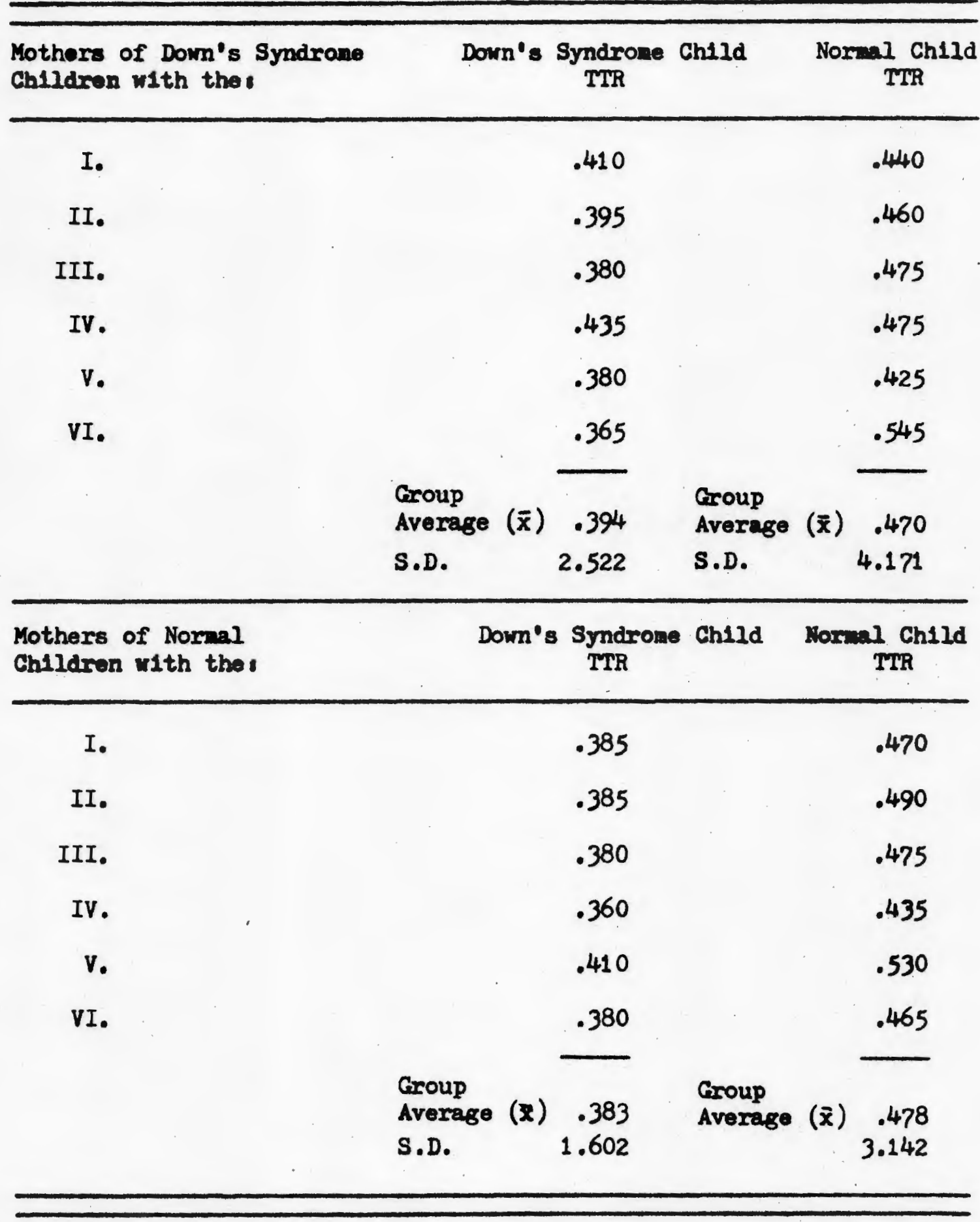


from .360 to .410 , and from .435 to .530 within spesches to the normal child.

Of Interest is the finding that individual nothers had consistently smaller TTRs within speeches to the child with Down's Syndrone than in speeches addrassed to the normal child. The averaged TIRs for all mothers of Down's Syndrome children in interactions with the Down's Symdrome child were .394 and .470 with the nomal child. The averaged TIRs for mothers of normal children in speeches presented to the child with Down's Syndrome were .383 and .478 for apeeches presented to the normal chlld.

To determine if the differences between the means were statistically significant, t-tosts were performed on averaged TIRs for interactions betweon each chlld for both groups of mothers. A thind t-test was performed for the pooled average TIR for all nothers in speches prosented to the Down's Syndrone child and the normal child. The three values of $t$ appear in Table II and indicate statistically significant differences in TTRs presented to the Down's Syndrome child and the normal child. An affirmation level of .01 was used to deteruine significance. 
TABLE II

t-Values for Average TIRs Addressed

to the Dow's Symdrome ChIld and the

Normal Ch1ld

\begin{tabular}{|c|c|c|c|}
\hline Conparison Groups & $t$ & $d f$ & p \\
\hline $\begin{array}{l}\text { Mothers of Normal Children with the Down's } \\
\text { Symdrome child vs. the normal child }\end{array}$ & 6.54 & 10 & $<.0005$ \\
\hline $\begin{array}{l}\text { Mothers of Down's Syndrome Children with } \\
\text { the Down's Syndrome child vs. the normel } \\
\text { child }\end{array}$ & 3.81 & 10 & $<.005$ \\
\hline $\begin{array}{l}\text { Mothers of Down's Symdrome children and } \\
\text { mothers of normal children, with the Down's } \\
\text { Symdrome child ve. the normal child }\end{array}$ & 7.27 & 22 & $<.0005$ \\
\hline
\end{tabular}

The 7.27 value of $t$ for all mothers in interactions with the Down's Syndrome child and the normal child is significant at the .0005 lovel of significance on a one-tailed test.

An Implicit question asked in the second and thind null hypotheses was whether statistically significant differences would occur in TTRs presented to each child between each group of mothers. T-tests were porformed to test these hypotheses. The results are presented in Table III. 
t-Values for Average TTRs

Presented Between Groups

of Mothers to Bach Child

\begin{tabular}{|c|c|c|c|}
\hline Comparison Groups & $t$ & df & $\mathrm{p}$ \\
\hline $\begin{array}{l}\text { Nothors of Normal Children vs. Mothers of } \\
\text { Down's Syndrome Children, with the Down's } \\
\text { Syndrome Child }\end{array}$ & .884 & 10 & $>.10$ \\
\hline $\begin{array}{l}\text { Notbars of Nomal Childran vs, Mothers of } \\
\text { Down's Symdrome Children, with the Normal } \\
\text { Child }\end{array}$ & .352 & 10 & 2.10 \\
\hline
\end{tabular}

A $t$ value of .884 Indicated no signiflcant difference between TIRs addressed to the Down's Syndrome child by groups of nothers. For average TIRs addressed to the normal child, a $t$ of .352 indicated no significant difference between groups of mothers of Down's Syndrome children and mothers of normal chtldren.

\section{DISEUSSION}

A statistically sioniflcant difference was obtained between type-token ratios presented by all mothers to the Down's Symdrome child and to the normal child.

All mothers used smaller TIRs with the Down's Syndrome child than those used with the normal child. Stated another way, all nothers used a smaller, lesser diverse vocabulary in interaction with the Down's Symdrome child than with the normal child. The results would lead this researcher to reject the first null hypothesis. 
The flndings lend support to the hypothesis that adult verbel behavior is influenced by the ingulstic characteristics of retarded children with whom they interact. As is indicated in Table I, scores for TIR presented to the two children show a distinct and consistent pattern across both groups of mothers. In terms of this one measure, all mothers modifled their language with quantitatively fewer numbers of words presented to the Down's Syndrone child.

In the present investigation, average TTRs of .394 and .383 were obtained in mothers" speeches to the Dow's Syndrome child. These are remarkably sinilar to those obtained in earlier studies. Adults assembled with Iow verbal retarded children in the Slegel (1963c) study had average TTRs of .390 as compared to .385 in the Slegel and Haxicln's (1963) study.

The verbal level of each chlld was sufficiently different to provide a contrast in the language characteristics they presented. Hothers in the study were essentlally interacting with two children of widely disparate language ablities and interests.

There are a number of things the mothers did in talking with the Down's Syndrome child which may have resulted in smaller TTRs. Informal observation of the sessions showed that most verbal interactions with the Down's Symdrome child dealt spocifically with the toys used during play. Comments directed to the child with Down's Syndrome appeared to be relatively "concrete," dealing with actual characteristics of the toys and the play activity.

In contrast, conversations with the normal child often seemed to center around activities and interests of both participants outside the immediate situation. The researcher felt these interactlons were 
of a more abstract nature. The apparent difference in abstraction levels of the conversations seems to be related to the verbal cues presented by each child. For example, open-ended questions presented to the child with Down's Syndrome, such as "What do you do in school?" or "What did you do on your vacation?" were often left ananswered. The child's linited response to these types of questions may have acted as a cue to the mothers to modify their conversation to a more restricted range of topics, e.g. the toys in the room. These informal observations agree with Spradin and Rosenberg's (1963) conclusions in research regarding binary and multiple questions in adult-reterded child interactions.

Though not evaluated in this otudy, the researcher felt the Down's Syndrome child nore often displayed confusion or non-understanding of verballations directed toward him than did the normal child. Non-understanding of the adult's speech was often indicated by the chlld's inapproprlate bahavior, such as an incorrect motoric response to a command. Many tines the child with Down's Syndrome would ask "What?" in response to a mother"s statenent, or completely 16nore her remark. Mothers were observed often to repeat whole phrases to the Down"s Symdrome child. These may be considered cues to the adult to modify her speech. Ilmiting the range of toplcs and use of simpler petterns seemed to be two such nodifications. It seened clear that the more concrete, simpler, and redundant verbalizations to the retarded child elloited greater comprehension and response. Eroen (1972) is in similar agreement from her research in verbal interactions of mother-normal child dyads. Such modifications to a more restricted 
language nay perhape be repponsible for the smaller TIR.

No statistically significant differences were found between TTRs prosented by mothers of nomal children and mothers of children with Down's Syndrone to the Down's Symdrome child. It would seen that the experience of a mother in ratsing her own retarded child did not cause her to modify her orn language to the Down's Syndrome child more than a nothor with normal children. Average TTRs for each group of mothers in Interactions with the Down's Syndrome child were nearly equal (Table Is Mothers of Down's Symdrome children - .394, mothers of normal children - .383). Similar findings wero obtained for both Broups of mothers in speeches addressed to the normal child (able Is Hothers of Down's Symdrome children - .470, Mothers of normal children.478). Thll hypotheses II and III therefore, were accepted.

What is yet unclear from these findings is whether adult verbal behavior when modified in this fashion, has a beneflcial influence on the language-learning child. Such modiflcations may lack the needed stimulation to enhance the retarded child's lingulstic growth. In the absence of a child's "nomal" response to verbal interaction, parents may inappropriately modify or partially extinguish speech to the retarded child. The complexity of this question increases as the child grows older. Parents may find it increasingly difficult to use simplified language with a physicaliy more meture retarded chlld, whose language is st1Il at a lower level. The opt1num, in this Instance, seens to be a language model whose structure is within the retarded child's comprohension, yet advanced enough to stimulate Iinguistic growth. Snow (1972, p. 564) states : 
The modifications which mothers produce for young children may be valuable in at least two ways. The first value, no doubt intended by the speaker, is to keep his speech simple. interesting, and comprehensible to young children. The second value unintended by the adult but potentially as important as the first, is that simplifled speech is admirably designed to aid children in learning language. This makes It somewhet easier to understand how a child can accomplish the formidable task of learning his native language with relative ease. The willingmess of the child's parents to produce sinplified and redundant speech, combined with the child's simple, meaningful, and comprehensible utterances, provide the child with tractable, relatively consistent, and relevant linguistic information from which to formulate the rules of gramnar.

\section{Qualifications}

The design of this research necessarily structured interactions of the Down's Syndrome child and the normal child with mothers who were not their own. The two chlldren served as a self-contained experinontal and control condition, eliminating the need to use controlled populations of mothers in interaction with their own children. It is of course impossible to state that each child was a representative eample of the retarded or normal population. Fach child did, however, present definite contrasts in Iinguistic ability to the nothers.

Since this investigation was conducted in a clinical setting. and assembled mothers with children who were not their own, it is difflcult to generalize freely from these findings to the actual inguistic environment of retarded children. There is no assurance that mothers talk and modify their language in the previously discussed manner with their own retarded children. The nother's language, however, did demonstrate significant diffarences between the two children. Durther, they vere asseabled in an unnatural situation. This may 
Indicate the effect of each child's varbal ability on the mother's expressive language was relatively powerful. 
CHAPTER V

SUMMARY AND IMPLICATIONS

\section{SUMMARY}

Recent investigations have focused on the nature of adult-child verbal interactions. The research has exantned the language of mothers and other adults when assembled with both normal and retarded children. The present study was undertaken to test the hypothesis that mothers of ch1ldren with Down's Syndrome and nothers of normal chlldren would present sintlar language characteristics to a Down's Syndrome child versus a normal child. Type-token rat1o, a measure of the subject's language diversification, was used as the behavioral measure.

The following null hypotheses were tested:

1. Averaged type-token retlos within speech addressed to the Down's Syndrome child will be equal to those addressed to the normal child by all mothers when considered as a group.

2. Mothers of children with Down's Syndrome will have type-token ratios equal to those of mothers of normal children in speech both groups of nothers address to the Down's Syndrone child.

3. Wothers of children with. Down's Syndrome will have type-token ratios equal to those of mothers of normal children in speech both groups of mothers address to the normal ch1ld.

The findings led to rejection of the first null hypothesis. 111 mothers presented smaller type-token ratios to the Down's Syndrome 
ch1ld than those addressed to the normal child. The rosults were signifleant at the .0005 level of confldence on a one-teiled test. No significant differences in type-token rat1o were found between groups of nothers of Down's Syndrome children and mothers of normal chlldren in speeches addressed to the Down's Syndrome child or to the normal child. Both groups of mothers modified their language sinilarly to each child. With regard to these findingt, the and and 3rd null hypotheses were accepted.

\section{IMPLICATIONS}

The results of this study suggest that differences in mother's language to a retarded child and a nornal child do exist. It would bo Interesting to determine if the present findings hold true for mothers with their own retarded child and an older, normal sibling. Would a young, normal child, matched for lenguage ablilty with an older, retarded child, elicit alnilar language characteristics fron nothers? Certainly it would elso seen appropriate to investigeto mothers.' langunge to a young, rotarded child and a normal, non-sibling of the same age, or, in another instance, an older, non-gibling. In addition, It would be interesting to study the retarded chlld's ability to respond to increasingly difficult lovels of verbal abstraction. How does varying the abstraction level affect his comprehension and expressive vocabulary? Would the prograning of Increasingly nore abstract vocabulary and syntax in language treatinent stimulate linguistic as well as cognitive growth?

Rurther, the effects of varying patterns of adult verbal behavior should be investigated. That kinds of verbalizations increase the 
retarded child's conprehension and cooperation? What kinds of Iinguistic stimulation Increase his spontaneous verbalization? The direction of research should progress tomard doternining the types of verbel nodels and stretegles that nost efflclently aid the retarded child's IIngulstic Growth. The reaults of research in these areas may very well have a profound impact on clinical treatment and parent counseling with the retarded child. 
Benda, C.F.: The Child ulth Mongolism, New York, Grune and Stratton, $(1960)$.

Brandeis, W. and Henderson, D. Social class, language, and communicat1on. Beverly Hills, Cal. : Sage Publications, 1970, as cited in Canden, C. Chlldren's Ianguage and Education. New York: Holt. Rinehart, and Winston, (1972).

Broen, P.A. The verbal environment of the language-learning child. J. Speech Hear. D1s. Monog. Suppl. \#12. (1972).

Brown, R. and Bellug1, U. Three processes in the child's acquisition of syntax. Hurvard Bucational Bovieu, Vol. 34, 133-151, (1964).

Carden, C. Environmental assistance to the child's acquisition of gramar. Dissertation Abstracts International, 29 (7-A). $2144-2145,(1969)$.

Cazden, C. Children's Lanquage and Education. New York: Holt, Rinehart, and winston, (1972).

Hegrenes, J.R., Marshall, N.R. and Coldstein, S. Verbal interactions, mothers and their retarded children vs. mothers and their nonretarded children. Amer. J. Ment. Defic.. 77, No. 4, 415-419, (1973).

Johnson, W., Darley, F. and Sprlestersbach, D. Diagnost1c Methods in Speech Pathology. Ner Yorki Harper and Ror (1963).

Jordan, T.E. The Mentally Retarded. New Yorki C.E. Merrill Co. (1960).

Lenneberg, B.H., Nichols, I.A. and Rosenberg, E.F. Primitive stages of language development in mongolism. A.R.N.M.D. Publications, 42. 119-137 (1962).

Mechan, M., Jex, L. and Jones, J. Utah Test of Ianquage Development. Salt Lake City: Communication Research Associates (1967).

Molyneaux, D. Childhood Ianguage Development. In Morris Val Jones (ed.) Ianguage Development, The Key to Learning. Springfleld. Illinols: Charles C. Thomas (1972).

Fillips, J.R. Formal characteristics of speech which mothers address to their young chlldren. Dissortation Abstracts International. 31. $(7-B), 4369-4370(1971)$.

Slegel, G.M. Adult verbel behavior in "play therapy" sessions with retarded chlldren. J. Speech Hear. Dtsord. Mong. Suppl. 10. 34-38 (1963a). 
Siegel, G.M. Verbal bohavior of retarded children assenbled with preins tructed adults. J. Speech Har, Msord. Monos. Suppl. 10 . 47-53 (1963b).

Slegel. G.H. Adult rerbal behavior with retarded children labeled as "high" or "low" in verbal ab1lity. Aner. J, Ment. Def1c., 38, $417-424$ (19630).

Slegel, G.M. and Harkins, J.P. Verbal bohavior of adults in two cond1tions with institutionalized retarded children. J. Speech Hear. Disord. Monog. Suppl. \#10. 30-46 (1963).

Skinner, B.F. Yerbel Bahav1or. Now York: Appleton-Century-Crofts (1957).

Snow, C. Ianguage acquisition and nother's speech to their children, as cited in Cazden, C. Children's Ianguage and Education. Now Yorki Holt, Rinehart, and Winston (1972).

Sprediln, J.E. and Rosenberg, S. Complexity of adult verbal behavior in a dyadic situation with retarded children, as cited in J. Speech Hear. Dlsord. Mong. Suppl. 110 (1963).

SpradIIn, J.E. and Rosenberg, S. Complexity of adult verbel behavior In a dyadic situation with retarded children. J. Abnorm. Soc. Prych. 68, No. 6, 694-698 (1964).

Tesplin, M.C. Cortain language skills in children, as cited in J. Speech Hear. Nonog. Suppl. t10, p. 37 (1963).

U1lkinson, A. The Poundation of Ianguage. Londons Oxford University Press (1971). 
APPERDIX

TOYS USED AS STIMULUS

ITTRS IN MOTHIRR-GHILD DYADS

1. Musical Dorris Whoel

2. Tool Bax (roal tools)

3. Tool Box (toy tools)

4. Leggos

5. Mational Goographle Magazines (3)

6. Pugzile of the U.S.

7. Toy Blocks

8. Pleture Dominoes

9. Toy train (wood type)

10. Grayons and Faper

11. Musical Merry-go-round

12. Chatter Box (Ideal Co.)

13. Toy Truek

14. Toy Helicopter

15. Boads and String

Protocol, Five different toys were chosen randomly from the pool of toys for each ten-minute session. 